\title{
Wnt signaling pathway as a regulator of bone formation and healing
}

Mohamed M. Elseweidy ${ }^{a}$, Sahar E. El-Swefy ${ }^{\mathrm{b}}$, Nourhan M. Baraka ${ }^{\mathrm{a}}$, Sally K. Hammad ${ }^{\mathrm{a}, *}$

aDepartment of Biochemistry, Faculty of Pharmacy, Zagazig University, Zagazig 44519, Egypt.

${ }^{b}$ Department of Biochemistry, Faculty of Pharmacy, Delta University, Gamasa, Egypt.

*Corresponding author. Email: Sally.k.hammad@hotmail.com

Received:20 Feb 2021 /Accepted: 23 Mar 2021 /Published online: 1 June 2021

\begin{abstract}
Bone is a mineralized structure that is mainly made of a matrix that supports the various types of bone cells; osteoblasts, osteoclasts, osteocytes and bone lining cells. Bone mass is preserved as a result of the balance between bone forming osteoblasts and bone resorbing osteoclasts, in a process known as bone remodeling. Bone remodeling process occurs mainly in three steps: resorption, reversal and formation. These steps are controlled locally and systemically by numerous regulatory factors. Among these regulatory factors, wingless-related MMTV integration site (Wnt) signaling pathway plays a significant role in maintainig bone mass as well as regulating many cellular processes. Based on whether $\beta$-catenin is involved or not, Wnt signaling is categorized into two main pathways; the canonical and the non-canonical pathways. The actions exerted by the Wnt signaling pathway are achieved when Wnt ligands bind to specific transmembrane receptors such as the Frizzled family (Frz) members and low density lipoprotein receptor-related proteins (LRPs) and are inhibited when these ligands or receptors bind to Wnt signaling inhibitors such as Wnt inhibitory factor 1 (WIF1), secreted Frizzledrelated proteins (sFRPs), Dickkopf 1 (DKK1) and sclerostin. Improper synthesis of any of these ligands, receptors or inhibitors leads to disruption of different body functions and progression of various diseases including skeletal diseases. Therefore, the components of the Wnt signaling pathway can be targeted for developing novel therapeutic agents to manage different diseases.
\end{abstract}

Keywords: Bone; Wnt ; Canonical ; Sclerostin ; Antagonist.

Running Title : Wnt signaling pathway as a regulator of bone formation and healing.

\section{Introduction}

Bone is a mineralized porous structure that generally consists of cells, vessels, and hydroxyapatite (calcium-containing crystals) and plays an important role in supporting the body and guarding its vital organs (Hadjidakis and Androulakis 2006; Buck and Dumanian 2012). A normal well-developed human skeleton is made of two types of bone with the same chemical constituents: the cortical bone, a thick and strong bone that comprises the outer layer of the skeleton; and the trabecular bone, a thinner and more flexible bone that forms the inner layer of the skeleton (le Noble and le Noble 2014).
Approximately $90 \%$ of the entire bone tissue consists of bone matrix which is chiefly composed of type I collagen fibers and noncollagenous proteins (Hadjidakis and Androulakis 2006). Bone matrix acts as a supporter and regulator for the activity of different bone cells; osteoblasts, osteocytes, osteoclasts and bone lining cells (Green, Schotland et al. 1995; Zohar 2012).

The bone mass is maintained by a well-balanced process known as bone remodeling which involves three steps; resorption, reversal and formation. These steps result in the removal of old bone and its replacement with new one (Hlaing and 
Compston 2014). This process is regulated by various local and systemic factors such as hormones, growth factors, and a number of immune system constituents (Florencio-Silva, Sasso et al. 2015). Disruption of this organized process or any of its regulatory factors is associated with development of a wide range of skeletal disorders (Houschyar, Tapking et al. 2019).

The wingless-related MMTV integration site (Wnt) signaling pathway includes a large group of glycoproteins that play a vital role in bone metabolism, development and homeostasis. Wnt components participate in controlling mesenchymal stem cell (MSC) differentiation. They enhance differentiation of MSCs into osteoblast while suppressing their differentiation into osteoclasts or adipocytes (Maeda, Kobayashi et al. 2019).

In this review, the process of bone remodeling, as well as its systemic and local regulation are covered. In addition, we discuss the components of the Wnt signaling pathway and their crucial role in bone formation, progression and management of various skeletal disorders.

\section{Bone modeling and remodeling}

The skeletal system is highly dynamic and undergoes several processes throughout life. In the developing skeleton, bone formation and resorption are not coupled together and occur separately. Therefore, length and diameter of long bones are increased. This process is known as bone modeling (Sugiyama and Oda 2017). On the other hand, the adult skeleton is different. The two processes are coupled and the old bone is replaced by new one to preserve bone mass. This process is known as bone remodeling (Sugiyama and Oda 2017).

The three main steps of the remodeling process are resorption, reversal and formation. The resorption phase starts with hydrochloric acid production by osteoclasts. Hydrochloric acid dissolves bone minerals. After that, the bone collagenous matrix is broken down by metalloproteases which are secreted by osteoclasts (Boyce 2013). Cathepsin K is the chief proteolytic enzyme secreted by osteoclasts. It breaks down collagen and other matrix proteins. Cathepsin $\mathrm{K}$ performs its function most efficiently at a low pH (Boyce 2013; Novack and Mbalaviele 2016).

Osteoclasts are then subjected to apoptosis and this is enhanced by the release of cytokines, such as transforming growth factor beta (TGFß1) (Hughes, Dai et al. 1996). This allows osteoblast progenitors to be attracted to the location (Tang, Wu et al. 2009). Moreover, macrophages help prepare the resorbed site for osteoblasts to start the formation of new bone (Sinder, Pettit et al. 2015). After the resorption process is accomplished, mononuclear cells emerge on the surface of the bone to prepare it for new bone formation and send signals that control migration and differentiation of osteoblasts. This step is known as the reversal phase (Hadjidakis and Androulakis 2006).

The last step is the formation phase in which new bone is formed by osteoblasts replacing the old resorbed one. This phase is followed by coverage of the bone surface with flattened lining cells and a long resting state starts till another remodeling cycle takes place (Hadjidakis and Androulakis 2006).

\section{Regulation of the bone remodeling process}

Bone remodeling is systemically and locally controlled by various factors including hormones, cytokines, growth factors, and some components of the immune system (Kim, Takai et al. 2003; Li, Xu et al. 2013; Yuan, Zhao et al. 2014).

Systemic regulation of bone remodeling involves crucial factors such as: calcitonin, parathyroid hormone, glucocorticoids, androgens, estrogens, and 1,25-dihydroxyvitamin D3. Estrogen is one of the most important factors that regulate bone 
mass and homeostasis. Estrogen is known to potentiate proliferation of osteoblasts and suppress their apoptosis. Moreover, it inhibits osteoclastogenesis and osteoclasts activity (Florencio-Silva, Sasso et al. 2015).

Local regulation on the other hand involves cytokines, prostaglandins released by bone cells, growth factors, as well as factors produced by the bone matrix during bone resorption (Florencio-Silva, Sasso et al. 2015). The main system that is involved in the local regulation of bone remodeling is the OPG/RANKL/RANK system. Receptor activator of nuclear factor kappa B ligand (RANKL) is a tumor necrosis factor family member released by osteoblasts and is essential for osteoclasts development and activation leading to bone resorption. Osteoprotegerin (OPG) is a decoy receptor that regulates attachment of RANKL to its RANK receptor. It competes with RANKL for RANK binding, thereby inhibiting osteoclast formation and bone resorption (Yasuda 2021). Suppression of RANKL production and stimulation of OPG release by osteoblasts is one of the mechanisms by which estrogen regulates bone homeostasis (Khosla, Oursler et al. 2012).

\section{Wnt signaling pathway}

Wnts represent a large group of glycoproteins that stimulate certain intracellular signaling cascades that regulate a wide variety of cellular activities including differentiation, proliferation, survival, apoptosis, polarity and migration. So far, about 19 Wnt proteins have been discovered and some of these forms are tissue specific (Manolagas 2014). Wnt signaling cascades are activated through binding of $\mathrm{Wnt}$ proteins to a diverse set of transmembrane receptors; including members of the Frizzled family (Frz), low density lipoprotein receptor-related proteins (LRPs) and receptor tyrosine kinase- like orphan receptors (Rors) (Gordon and Nusse 2006).

Wnt signaling pathway is classified mainly into two classes (Figure 1), both of which are involved in regulating bone metabolism and development, in addition to homeostasis of numerous organs. These two classes are the canonical pathway which involves $\beta$-catenin utilization and the noncanonical pathway which does not involve $\beta$ catenin utilization (James 2013; Kobayashi, Uehara et al. 2015; Kobayashi, Uehara et al. 2016; Maeda, Kobayashi et al. 2019).

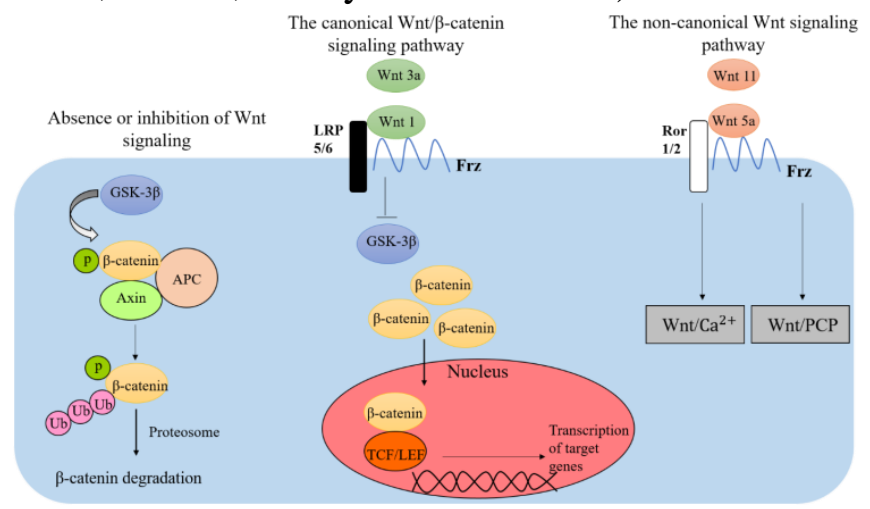

Figure 1. Wnt signaling pathway (canonical and non-canonical).

Wnt: wingless-related MMTV integration site, LRP: low-density lipoprotein-related receptor, Frz: frizzled, GSK-3 $\beta$ : glycogen synthase kinase-3 $\beta$, TCF: T-cell factor, LEF: lymphocyte enhancer factor, Ror 1/2: receptor tyrosine kinase-like orphan receptor 1/2, PCP: planar cell Polarity, APC: adenomatous polyposis coli. Figure adapted from (Maeda, Kobayashi et al. 2019)

\section{Canonical and non-canonical Wnt signaling pathways}

The canonical Wnt signaling pathway depends on the presence of $\beta$-catenin. When Wnt signaling is absent, $\beta$-catenin accumulation is prevented as a result of its rapid phosphorylation and destruction. $\beta$ catenin phosphorylation is mediated by glycogen synthase kinase-3 $\beta$ (GSK-3 $\beta$ ), Axin 
and adenomatous polyposis coli (APC) complex. This is followed by ubiquitination and proteasomal degradation. Alternatively, if Wnt signaling is stimulated by ligands such as Wnt1 and Wnt 3a, GSK-3 $\beta$ activity is reduced and $\beta$-catenin is accumulated in the cytoplasm then it is transported to the nucleus to trigger the expression of target genes (Kobayashi, Maeda et al. 2008; Maeda, Kobayashi et al. 2019).

The non-canonical Wnt signaling pathway is independent on the presence or accumulation of $\beta$-catenin. Instead, it can be activated via ligands such as Wnt5a and Wnt11. The Wnt/calcium pathway is an example of the non-canonical Wnt signaling pathways in which protein kinase $\mathrm{C}$ and calmodulin-dependent protein kinase II are activated as a result of the elevated intracellular calcium concentration. Another example is the Wnt/planar cell polarity pathway, in which cell motility is enhanced and cilia direction is determined by the activation of small $\mathrm{G}$ proteins (Maeda, Kobayashi et al. 2019).

\section{Inhibition of Wnt signaling pathways}

Both canonical and non-canonical Wnt signaling pathways are inhibited when Wnt ligands bind to Wnt inhibitory factor 1 (WIF1) and secreted Frizzled-related proteins (sFRPs). The canonical Wnt signaling pathway, in addition, can be inhibited when Dickkopf 1 (DKK1) and sclerostin bind to LRP extracellular domain, suppressing the interaction between Wnt ligands and LRP and Frz (Lerner and Ohlsson 2015).

\section{The role of Wnt signaling in maintaining bone mass}

Osteoblasts, the bone forming cells, and osteoclasts, the bone resorbing cells, are derived from different types of precursers under the regulation of various transcription factors. Osteoblasts are derived from mesenchymal stem cells (MSCs) while osteoclasts are derived from macrophagelineage cells and monocytes. Both canonical and non-canonical Wnt signaling pathways are involved in regulation of osteoblast and osteoclast differentiation through different mechanisms (Maeda, Kobayashi et al. 2019).

The canonical Wnt $/ \beta$-catenin signaling pathway is known to play an important role in favoring osteoblastic differentiation of MSCs over chondrogenic and adipogenic differentiation. This is achieved by upregulating the expression of osteogenic regulatory factors, such as runt-related transcription factor 2 (RUNX2) and osterix, along with downregulation of the adipogenic factors expression, such as peroxisome proliferator-activated receptor gamma (PPARr) (Houschyar, Tapking et al. 2019). RUNX2 is a key transcription factor that is involved in the development of the skeletal system. It performs a crucial role in osteoblastic differentiation and osteoprogenitor proliferation (Komori 2020). PPARr on the other hand, is a chief transcription factor that functions mainly to enhance adipogenic and prevent osteoblastic differentiation (Yuan, Li et al. 2016). The canonical Wnt signaling pathway, in addition, suppresses osteoclast proliferation and number by potentiating OPG production and release (Glass, Bialek et al. 2005).

On the other hand, it has been suggested that depending on the type of Wnt protein involved, the non-canonical signaling can either stimulate or suppress osteoclastic differentiation. For example, Wnt5a can stimulate osteoclast formation while Wnt4 and Wnt16 have the opposite effect (Kobayashi, Uehara et al. 2016).

The role of Wnt signaling in development and management of skeletal disorders

Due to the important role of Wnt signaling in the development of numerous organ systems and in the bone remodeling 
process, various Wnt components are involved in the pathogenesis of skeletal disorders (Table 2). Therefore, Wnt signaling pathway can be employed as an effective target for management of bone diseases. Regeneration of bone via Wnt signaling can be achieved either by adding more agonists or inhibiting the existing antagonists. Since the first approach is very costly, suppressing antagonists seems to be more applicable (Hoeppner, Secreto et al. 2009).

Table 1. List of abbreviations

\begin{tabular}{cc}
\hline APC & Adenomatous polyposis coli \\
\hline DKK1 & Dickkopf 1 \\
Frz & Frizzled family \\
GSK-3 $\beta$ & Glycogen synthase kinase-3 $\beta$ \\
LRPs & low density lipoprotein receptor-related proteins \\
MDK & Midkine \\
MSCs & Mesenchymal stem cells \\
OPG & Osteoprotegerin \\
Porc & Porcupine \\
PPARr & Peroxisome proliferator-activated receptor gamma \\
RANKL & Receptor activator of nuclear factor $\kappa$-B ligand \\
RNF43 & Ring finger 43 \\
Ror2 & Receptor tyrosine kinase-like orphan receptor 2 \\
RSPO 2 & Roof-plate specific spondin 2 \\
RUNX2 & Runt-related transcription factor 2 \\
SFRPs & Secreted Frizzled-related proteins \\
SOST & Sclerostin gene \\
TGF $\beta 1$ & Transforming growth factor beta \\
WIF1 & Wnt inhibitory factor 1 \\
Wnt & Zinc and ring finger 3 \\
ZNRF3 & wingless-related MMTV integration site \\
\hline
\end{tabular}

Table 2. Wnt signaling components and their role in the development of skeletal disorders.

\begin{tabular}{|c|c|c|c|c|c|}
\hline Disease & Mutated gene & $\begin{array}{c}\text { Effect of } \\
\text { mutation on } \\
\text { gene function }\end{array}$ & $\begin{array}{l}\text { Role in Wnt } \\
\text { signaling }\end{array}$ & Effect on bone & References \\
\hline Sclerosteosis & $\begin{array}{l}\text { sclerostin } \\
\text { gene (SOST) }\end{array}$ & Reduced & $\begin{array}{l}\text { Sclerostin binds to } \\
\text { LRP5/6 leading to } \\
\text { suppression of } \\
\text { canonical Wnt } \\
\text { signaling pathway. }\end{array}$ & $\begin{array}{l}\text { Elevated bone } \\
\text { mineral density } \\
\text { and thickened } \\
\text { cortical bone. }\end{array}$ & $\begin{array}{l}\text { (Balemans, } \\
\text { Ebeling et al. } \\
2001 ; \\
\text { Brunkow, } \\
\text { Gardner et al. } \\
\text { 2001; van } \\
\text { Lierop, } \\
\text { Appelman- } \\
\text { Dijkstra et al. } \\
\text { 2017) }\end{array}$ \\
\hline
\end{tabular}




$\begin{array}{lll}\begin{array}{l}\text { Tetra-amelia } \\ \text { syndrome }\end{array} & \begin{array}{l}\text { Roof-plate } \\ \text { specific }\end{array} & \text { Reduced } \\ & \text { spondin 2 } & \\ & \text { (RSPO2) }\end{array}$

Osteoporosispseudoglioma syndrome

Hyperostosis

$\begin{array}{ll}\begin{array}{l}\text { Endosteal } \\ \text { hyperostosis / }\end{array} & \begin{array}{l}\text { SOST } \\ \text { (removal of }\end{array} \\ \text { van Buchem } & 52 \text { kbps } \\ \text { disease } & \begin{array}{l}\text { downstream } \\ \text { of SOST } \\ \text { gene) }\end{array}\end{array}$

Osteosclerosis LRP4 Reduced

Focal dermal hypoplasia / Goltz-Gorlin syndrome

LRP5 Reduced

LRP5 Increased

Reduced

Porcupine Reduced (Porc)
RSPO2 is an antagonist for ring finger 43 (RNF43) and zinc and ring finger 3 (ZNRF3).

RNF43 and ZNRF3 expression results in degradation of Frz proteins and suppression of Wnt signaling.

Wnt receptor to which both Wnt proteins and antagonists bind to stimulate or inhibit Wnt signaling, respectively.

Wnt receptor to which both Wnt proteins and antagonists bind to stimulate or inhibit Wnt signaling, respectively.

Sclerostin binds to

LRP5/6 leading to suppression of canonical Wnt signaling pathway.

Sclerostin binds to LRP4 exerting an inhibitory effect on canonical Wnt signaling (negative regulation)

Porc is an acyltransferase that is located in the endoplasmic reticulum and is responsible for lipidation of Wnt proteins by palmitoleic
Total loss of Limbs.

(Szenker-Ravi, Altunoglu et al. 2018)
Osteoporosis

Elevated bone mineral density and torus palatinus

Increased bone mass

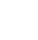


acid.

\begin{tabular}{|c|c|c|c|c|c|}
\hline $\begin{array}{l}\text { Osteogenesis } \\
\text { imperfecta and } \\
\text { juvenile } \\
\text { osteoporosis }\end{array}$ & Wnt1 & Reduced & $\begin{array}{l}\text { A component of the } \\
\text { canonical Wnt } \\
\text { pathway. }\end{array}$ & $\begin{array}{l}\text { Reduced bone } \\
\text { mineral density, } \\
\text { repeated fractures } \\
\text { and } \\
\text { deformation of } \\
\text { bone }\end{array}$ & $\begin{array}{l}\text { (Laine, Joeng } \\
\text { et al. 2013) }\end{array}$ \\
\hline $\begin{array}{l}\text { Metaphyseal } \\
\text { Dysplasia / } \\
\text { Pyle's disease }\end{array}$ & sFRP4 & Reduced & $\begin{array}{l}\text { The sFRP family } \\
\text { members antagonize } \\
\text { both canonical and } \\
\text { non-canonical Wnt } \\
\text { signaling. }\end{array}$ & $\begin{array}{l}\text { Bone brittleness, } \\
\text { cortical bone } \\
\text { thinning and wide } \\
\text { trabecular } \\
\text { metaphyses. }\end{array}$ & $\begin{array}{l}\text { (Simsek Kiper, } \\
\text { Saito et al. } \\
\text { 2016) }\end{array}$ \\
\hline $\begin{array}{l}\text { Robinow } \\
\text { syndrome }\end{array}$ & $\begin{array}{l}\text { Wnt5a or } \\
\text { Ror } 2\end{array}$ & Reduced & $\begin{array}{l}\text { Components of the } \\
\text { non-canonical Wnt } \\
\text { pathway. }\end{array}$ & $\begin{array}{l}\text { Shortening of the } \\
\text { limbs and } \\
\text { deformities in the } \\
\text { ribs and } \\
\text { vertebrae. }\end{array}$ & $\begin{array}{l}\text { (Patton and } \\
\text { Afzal 2002; } \\
\text { Roifman, } \\
\text { Marcelis et al. } \\
\text { 2015) }\end{array}$ \\
\hline
\end{tabular}

\section{Inhibition of sclerostin and DKK1}

Sclerostin and DKK1 are naturally occurring glycoproteins that suppress Wnt signaling, thus antibodies directed against either one of them will enhance Wnt signaling and bone formation. Romosozumab is a monoclonal antibody that targets sclerostin and suppresses its action. It is approved in the US and many countries as an anabolic agent for management of osteoporosis due to its beneficial action in enhancing bone formation and preventing bone resorption (Paik and Scott 2020). Similarly, anti-DKK1 antibodies have been reported to have the ability to shift the balance towards bone formation, but they are still under clinical investigation (Awasthi, Mani et al. 2018). Recently, an antibody that is directed against both DKK1 and sclerostin has shown a greater ability to heal fractures induced in mice than using individual antibodies (Florio, Gunasekaran et al. 2016).

\section{Inhibition of sFRPs}

sFRPs are a family of Wnt antagonists that suppress the interaction between Wnt ligands and their receptors. sFRP-1, in particular, is a negative Wnt signaling regulator that inhibits the canonical $\mathrm{Wnt} / \beta$ catenin signaling (Bodine, Robinson et al. 2006). Elevated sFRP-1 levels in osteoblasts have been shown to suppress Wnt signaling, thus inhibiting osteoblastic differentiation and survival (Bodine, Billiard et al. 2005; Bodine, Robinson et al. 2006). On the other hand, mice with deleted sFRP-1 gene demonstrated enhanced trabecular bone and potentiated osteoblastic differentiation and activity, as a result of stimulated Wnt signaling (Bodine, Zhao et al. 2004). Although the clinical application of sFRP-1 inhibitors remains under investigation, in vitro studies suggest that diphenyl sulfone sulfonamide could suppress apoptosis of preosteocytes via inhibitng sFRP-1 (Moore, Kern et al. 2009). In addition, sFRP-1 antibody was able to prevent periodontal bone damage and 
osteoclastogenesis in a murine model of periodontitis (Li and Amar 2007).

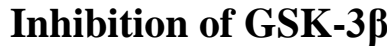

GSK-3 $\beta$ negatively regulates bone formation through facilitating $\beta$-catenin phosphorylation and subsequently its degradation, which makes it a negative regulator of Wnt signaling. Previous studies revealed that GSK-3 $\beta$ inhibitors were successfully employed to treat long bone fractures (Schupbach, Comeau-Gauthier et al. 2020). Lithium is a promising GSK-3 $\beta$ inhibitor. Its effects were observed when bipolar patients treated with lithium showed decreased fracture risk and elevated bone mineral density (Vestergaard, Rejnmark et al. 2005; Zamani, Omrani et al. 2009). Numerous studies have proved the efficacy of lithium compounds, such as lithium chloride and carbonate, in facilitating recovery from fractures and enhancing bone formation. Further investigations are required to develop safer GSK-3 $\beta$ inhibitors that work specifically on osteoblasts and can be used as a long-term medication for treatment of osteoporosis and osteopenia (Schupbach, Comeau-Gauthier et al. 2020).

\section{Inhibition of midkine}

Midkine (MDK) is a growth factor that has the ability to bind various receptors like LRP6, exerting a negative effect on the canonical Wnt signaling. It is expressed exclusively in long bones, kidneys and brains of fully-grown organisms but its expression can be locally elevated in states of inflammation such as acute fractures. It is also secreted throughout the stages of fracture healing (Liedert, Schinke et al. 2014; HaffnerLuntzer 2020). Haffner-Luntzer et al. demonstrated that treatment of ovariectomized and middle-aged mice with MDK antibody could stimulate bone formation and ameliorate femoral fractures. This was thought to be due to the augmented $\mathrm{Wnt} / \beta$ catenin signaling that potentiated osteoblastic action (Haffner-Luntzer, Heilmann et al. 2016; Haffner-Luntzer, Kemmler et al. 2016). Moreover, a clinical study showed that MDK levels are elevated in patients suffering from fractures, particularly postmenopausal female patients, indicating the significance of employing MDK antibodies in speeding up recovery from fractures (Fischer, Kalbitz et al. 2018).

Other therapeutic agents used in management of bone diseases

Metabolic bone diseases represent a serious health problem globally and are mainly characterized by irregular bone structure and mass (El Demellawy, Davila et al. 2018). Numerous drugs have been employed in management of metabolic bone diseases and are mainly classified into 2 categories: antiresorptive drugs which suppress bone resorption and anabolic drugs which augment bone formation (Tu, Lie et al. 2018).

Bisphosphonates are a large group of antiresorptive drugs that have been prescribed for treatment of bone disorders, mainly osteoporosis, for decades (Drake, Cremers et al. 2019). Their antiresorptive action is due to their ability to prevent osteoclast function and enhance osteoclast apoptosis (Singh and Gonegandla 2019). Regardless of the beneficial clinical role of bisphosphonates, their long-term use is limited due to the associated adverse effects including osteonecrosis of the jaw, osteomalacia, atypical femoral fractures, and gastrointestinal side effects (Awasthi, Mani et al. 2018).

Due to its significant role in regulating bone remodeling, estrogen as well as estrogen agonists are widely used in management of osteoporosis. However, the preventive use of estrogen replacement therapy against osteoporosis is not recommended because of the increased possibility of cancer development including uterine and breast 
cancers. On the other hand, estrogen agonists such as selective estrogen receptor modulators can bind to estrogen receptors and perform their function without causing its severe side effects (Tabatabaei-Malazy, Salari et al. 2017).

Anabolic drugs are another category of medications that are used for management of bone disease. Teriparatide and abaloparatide are recombinant human parathyroid hormone that are approved for osteoporosis treatment as anabolic agents. Their intermittent administration potentiates osteoblast action, diminishes DKK1 and stimulates Wnt signaling. On the contrary, their continuous long-term administration is associated with elevated rate of bone resorption and risk of osteosarcoma (Noh, Yang et al. 2020).

\section{Conclusion}

The Wnt signaling pathway is a vital regulatory pathway that participates in many cellular functions including differentiation, migration and apoptosis, as well as controlling skeletal integrity. There are two main Wnt signaling pathways, the canonical and the non-canonical, which are both involved in preserving bone mass and regulating bone formation and resorption. The Wnt signaling pathway includes a variety of components that can be considered as underlying causes of different diseases and therefore important targets for disease management.

\section{References}

Awasthi, H.,D. Mani,D. Singh and A. Gupta (2018). The underlying pathophysiology and therapeutic approaches for osteoporosis. Medicinal Research Reviews 38(6): 2024-2057.

Balemans, W.,M. Ebeling,N. Patel,E. Van Hul,P. Olson,M. Dioszegi,C. Lacza,W. Wuyts,J. Van Den Ende,P. Willems,A.F. Paes-Alves,S. Hill,M.
Bueno,F.J. Ramos,P. Tacconi,F.G. Dikkers,C. Stratakis,K. Lindpaintner,B. Vickery,D. Foernzler and W. Van Hul (2001). Increased bone density in sclerosteosis is due to the deficiency of a novel secreted protein (SOST). Human Molecular Genetics 10(5): 537-544.

Balemans, W.,N. Patel,M. Ebeling,E. Van Hul,W. Wuyts,C. Lacza,M. Dioszegi,F.G. Dikkers,P. Hildering,P.J. Willems,J.B.G.M. Verheij,K. Lindpaintner,B. Vickery,D. Foernzler and W. Van Hul (2002). Identification of a $52 \mathrm{~kb}$ deletion downstream of the <em>SOST</em> gene in patients with van Buchem disease. Journal of Medical Genetics 39(2): 91-97.

Bodine, P.V.,J. Billiard,R.A. Moran,H. Poncede-Leon,S. McLarney,A. Mangine,M.J. Scrimo,R.A. Bhat,B. Stauffer,J. Green,G.S. Stein,J.B. Lian and B.S. Komm (2005). The Wnt antagonist secreted frizzled-related protein-1 controls osteoblast and osteocyte apoptosis. J Cell Biochem 96(6): 1212-1230.

Bodine, P.V.N.,J.A. Robinson,R.A. Bhat,J. Billiard,F.J. Bex and B.S. Komm (2006). The role of Wnt signaling in bone and mineral metabolism. Clinical Reviews in Bone and Mineral Metabolism 4(2): 73-96.

Bodine, P.V.N.,W. Zhao,Y.P. Kharode,F.J. Bex,A.-J. Lambert,M.B. Goad,T. Gaur,G.S. Stein,J.B. Lian and B.S. Komm (2004). The Wnt Antagonist Secreted Frizzled-Related Protein-1 Is a Negative Regulator of Trabecular Bone Formation in Adult Mice. Molecular Endocrinology 18(5): 1222-1237.

Boyce, B.F. (2013). Advances in osteoclast biology reveal potential new drug targets and new roles for osteoclasts. 
Journal of Bone and Mineral Research 28(4): 711-722.

Brunkow, M.E.,J.C. Gardner,J. Van Ness,B.W. Paeper,B.R. Kovacevich,S. Proll,J.E. Skonier,L. Zhao,P.J. Sabo,Y. Fu,R.S. Alisch,L. Gillett,T. Colbert,P. Tacconi,D. Galas,H. Hamersma,P. Beighton and J. Mulligan (2001). Bone dysplasia sclerosteosis results from loss of the SOST gene product, a novel cystine knot-containing protein. American journal of human genetics 68(3): 577-589.

Buck, D.W.I. and G.A. Dumanian (2012). Bone Biology and Physiology: Part I. The Fundamentals. Plastic and Reconstructive Surgery 129(6): 13141320.

Drake, M.T.,S. Cremers,R.G. Russell and J.P. Bilezikian (2019). Drugs for the treatment of metabolic bone diseases. British Journal of Clinical Pharmacology 85(6): 1049-1051.

El Demellawy, D.,J. Davila,A. Shaw and Y. Nasr (2018). Brief Review on Metabolic Bone Disease. Acad Forensic Pathol 8(3): 611-640.

Fischer, V.,M. Kalbitz,F. Müller-Graf,F. Gebhard,A. Ignatius,A. Liedert and M. Haffner-Luntzer (2018). Influence of Menopause on Inflammatory Cytokines during Murine and Human Bone Fracture Healing. Int J Mol Sci 19(7).

Florencio-Silva, R.,G.R. Sasso,E. SassoCerri,M.J. Simões and P.S. Cerri (2015). Biology of Bone Tissue: Structure, Function, and Factors That Influence Bone Cells. BioMed research international 2015: 421746.

Florio, M.,K. Gunasekaran,M. Stolina,X. Li,L. Liu,B. Tipton,H. SalimiMoosavi,F.J. Asuncion,C. Li,B. Sun,H.L. Tan,L. Zhang,C.Y. Han,R. Case,A.N. Duguay,M. Grisanti,J. Stevens,J.K. Pretorius,E. Pacheco,H.
Jones,Q. Chen,B.D. Soriano,J. Wen,B. Heron,F.W. Jacobsen,E. Brisan,W.G. Richards,H.Z. Ke and M.S. Ominsky (2016). A bispecific antibody targeting sclerostin and DKK-1 promotes bone mass accrual and fracture repair. Nature communications 7: 11505 .

Glass, D.A., 2nd,P. Bialek,J.D. Ahn,M. Starbuck,M.S. Patel,H. Clevers,M.M. Taketo,F. Long,A.P. McMahon,R.A. Lang and G. Karsenty (2005). Canonical Wnt signaling in differentiated osteoblasts controls osteoclast differentiation. Developmental cell 8(5): 751-764.

Gong, Y.,R.B. Slee,N. Fukai,G. Rawadi,S. Roman-Roman,A.M. Reginato,H. Wang,T. Cundy,F.H. Glorieux,D. Lev,M. Zacharin,K. Oexle,J. Marcelino,W. Suwairi,S. Heeger,G. Sabatakos,S. Apte,W.N. Adkins,J. Allgrove,M. Arslan-Kirchner,J.A. Batch,P. Beighton,G.C.M. Black,R.G. Boles,L.M. Boon,C. Borrone,H.G. Brunner,G.F. Carle,B. Dallapiccola,A. De Paepe,B. Floege,M.L. Halfhide,B. Hall,R.C. Hennekam,T. Hirose,A. Jans,H. Jüppner,C.A. Kim,K. KepplerNoreuil,A. Kohlschuetter,D. LaCombe,M. Lambert,E. Lemyre,T. Letteboer,L. Peltonen,R.S. Ramesar,M. Romanengo,H. Somer,E. Steichen-Gersdorf,B. Steinmann,B. Sullivan,A. Superti-Furga,W. Swoboda,M.-J. van den Boogaard,W. Van Hul,M. Vikkula,M. Votruba,B. Zabel,T. Garcia,R. Baron,B.R. Olsen and M.L. Warman (2001). LDL Receptor-Related Protein 5 (LRP5) Affects Bone Accrual and Eye Development. Cell 107(4): 513-523.

Gordon, M.D. and R. Nusse (2006). Wnt signaling: multiple pathways, multiple receptors, and multiple transcription factors. The Journal of biological chemistry 281(32): 22429-22433. 
Green, J.,S. Schotland,D.J. Stauber,C.R Kleeman and T.L. Clemens (1995). Cell-matrix interaction in bone: type I collagen modulates signal transduction in osteoblast-like cells. The American journal of physiology 268(5 Pt 1): C1090-1103.

Grzeschik, K.-H.,D. Bornholdt,F. Oeffner,A. König,M. del Carmen Boente,H. Enders,B. Fritz,M. Hertl,U. Grasshoff,K. Höfling,V. Oji,M. Paradisi,C. Schuchardt,Z. Szalai,G. Tadini,H. Traupe and R. Happle (2007). Deficiency of PORCN, a regulator of Wnt signaling, is associated with focal dermal hypoplasia. Nature Genetics 39(7): 833-835.

Hadjidakis, D.J. and I.I. Androulakis (2006). Bone Remodeling. Annals of the New York Academy of Sciences 1092(1): 385-396.

Haffner-Luntzer, M. (2020). Experimental agents to improve fracture healing: utilizing the WNT signaling pathway. Injury.

Haffner-Luntzer, M.,A. Heilmann,A.E. Rapp,R. Roessler,T. Schinke,M. Amling,A. Ignatius and A. Liedert (2016). Antagonizing midkine accelerates fracture healing in mice by enhanced bone formation in the fracture callus. British Journal of Pharmacology 173(14): 2237-2249.

Haffner-Luntzer, M.J. Kemmler,V. Heidler,K. Prystaz,T. Schinke,M. Amling,A. Kovtun,A.E. Rapp,A. Ignatius and A. Liedert (2016). Inhibition of Midkine Augments Osteoporotic Fracture Healing. PLOS ONE 11(7): e0159278.

Hlaing, T.T. and J.E. Compston (2014). Biochemical markers of bone turnover - uses and limitations. Annals of Clinical Biochemistry 51(2): 189-202.
Hoeppner, L.H.,F.J. Secreto and J.J. Westendorf (2009). Wnt signaling as a therapeutic target for bone diseases. Expert opinion on therapeutic targets 13(4): 485-496.

Houschyar, K.S.,C. Tapking,M.R. Borrelli,D. Popp,D. Duscher,Z.N. Maan,M.P. Chelliah,J. Li,K. Harati,C. Wallner,S. Rein,D. Pförringer,G. Reumuth,G. Grieb,S. Mouraret,M. Dadras,J.M. Wagner,J.Y. Cha,F. Siemers,M. Lehnhardt and B. Behr (2019). Wnt Pathway in Bone Repair and Regeneration - What Do We Know So Far. Frontiers in Cell and Developmental Biology 6(170).

Hughes, D.E.,A. Dai,J.C. Tiffee,H.H. Li,G.R. Mundy and B.F. Boyce (1996). Estrogen promotes apoptosis of murine osteoclasts mediated by TGFbeta. Nat Med 2(10): 1132-1136.

James, A.W. (2013). Review of Signaling Pathways Governing MSC Osteogenic and Adipogenic Differentiation. Scientifica 2013: 684736.

Johnson, M.L.,K. Harnish,R. Nusse and W. Van Hul (2004). LRP5 and Wnt Signaling: A Union Made for Bone. Journal of Bone and Mineral Research 19(11): 1749-1757.

Khosla, S.,M.J. Oursler and D.G. Monroe (2012). Estrogen and the skeleton. Trends Endocrinol Metab 23(11): 576-581.

Kim, C.H.,E. Takai,H. Zhou,D. Von Stechow,R. Müller,D.W. Dempster and X.E. Guo (2003). Trabecular Bone Response to Mechanical and Parathyroid Hormone Stimulation: The Role of Mechanical Microenvironment. Journal of Bone and Mineral Research 18(12): 21162125.

Kobayashi, Y.,K. Maeda and N. Takahashi (2008). Roles of Wnt signaling in bone 
formation and resorption. Japanese Dental Science Review 44(1): 76-82.

Kobayashi, Y.,S. Uehara,M. Koide and N. Takahashi (2015). The regulation of osteoclast differentiation by Wnt signals. BoneKEy reports 4: 713.

Kobayashi, Y.,S. Uehara,N. Udagawa and N. Takahashi (2016). Regulation of bone metabolism by Wnt signals. Journal of biochemistry 159(4): 387-392.

Koide, M. and Y. Kobayashi (2019). Regulatory mechanisms of sclerostin expression during bone remodeling. Journal of Bone and Mineral Metabolism 37(1): 9-17.

Komori, T. (2020). Molecular Mechanism of Runx2-Dependent Bone Development. Mol Cells 43(2): 168-175.

Laine, C.M.,K.S. Joeng,P.M. Campeau,R. Kiviranta,K. Tarkkonen,M. Grover,J.T. Lu,M. Pekkinen,M. Wessman,T.J. Heino,V. NieminenPihala,M. Aronen,T. Laine,H. Kröger,W.G. Cole,A.-E. Lehesjoki,L. Nevarez,D. Krakow,C.J.R. Curry,D.H. Cohn,R.A. Gibbs,B.H. Lee and O. Mäkitie (2013). WNT1 Mutations in Early-Onset Osteoporosis and Osteogenesis Imperfecta. New England Journal of Medicine 368(19): 1809-1816.

le Noble, F. and J. le Noble (2014). Vessels of rejuvenation. Nature 507(7492): 313314.

Lerner, U.H. and C. Ohlsson (2015). The WNT system: background and its role in bone. Journal of Internal Medicine 277(6): 630-649.

Leupin, O.,E. Piters,C. Halleux,S. Hu,I. Kramer,F. Morvan,T. Bouwmeester,M. Schirle,M. BuenoLozano,F.J.R. Fuentes,P.H. Itin,E. Boudin,F. de Freitas,K. Jennes,B. Brannetti,N. Charara,H. Ebersbach,S. Geisse,C.X. Lu,A. Bauer,W. Van Hul and M. Kneissel (2011). Bone overgrowth-associated mutations in the LRP4 gene impair sclerostin facilitator function. The Journal of biological chemistry 286(22): 1948919500.

Li, C.H. and S. Amar (2007). Inhibition of SFRP1 reduces severity of periodontitis. Journal of dental research 86(9): 873-877.

Li, X.,R.-S. Xu,D.-L. Jiang,X.-L. He,C. Jin,W.-G. Lu,Q. Su and F.-L. Yuan (2013). Acid-sensing ion channel 1a is involved in acid-induced osteoclastogenesis by regulating activation of the transcription factor NFATc1. FEBS Letters 587(19): 3236-3242.

Liedert, A.,T. Schinke,A. Ignatius and M. Amling (2014). The role of midkine in skeletal remodelling. British Journal of Pharmacology 171(4): 870-878.

Maeda, K.,Y. Kobayashi,M. Koide,S. Uehara,M. Okamoto,A. Ishihara,T. Kayama,M. Saito and K. Marumo (2019). The Regulation of Bone Metabolism and Disorders by Wnt Signaling. International Journal of Molecular Sciences 20(22): 5525.

Manolagas, S.C. (2014). Wnt signaling and osteoporosis. Maturitas 78(3): 233237.

Moore, W.J.,J.C. Kern,R. Bhat,T.J. Commons,S. Fukayama,I. Goljer,G. Krishnamurthy,R.L. Magolda,L. Nogle,K. Pitts,B. Stauffer,E.J. Trybulski,G.S. Welmaker,M. Wilson and P.V. Bodine (2009). Modulation of Wnt signaling through inhibition of secreted frizzled-related protein I (sFRP-1) with N-substituted piperidinyl diphenylsulfonyl sulfonamides. J Med Chem 52(1): 105-116.

Noh, J.Y.,Y. Yang and H. Jung (2020). Molecular Mechanisms and Emerging 
Therapeutics for Osteoporosis. Int $\mathbf{J}$ Mol Sci 21(20).

Novack, D.V. and G. Mbalaviele (2016). Osteoclasts-Key Players in Skeletal Health and Disease. Microbiology spectrum 4(3):

10.1128/microbiolspec.MCHD-00112015.

Paik, J. and L.J. Scott (2020). Romosozumab:

A Review in Postmenopausal Osteoporosis. Drugs \& aging 37(11): 845-855.

Patton, M.A. and A.R. Afzal (2002). Robinow syndrome. Journal of Medical Genetics 39(5): 305-310.

Roifman, M.,C.L.M. Marcelis,T. Paton,C. Marshall,R. Silver,J.L. Lohr,H.G. Yntema,H. Venselaar,H. Kayserili,B. van Bon,G. Seaward,F.C. Consortium,H.G. Brunner and D. Chitayat (2015). De novo WNT5Aassociated autosomal dominant Robinow syndrome suggests specificity of genotype and phenotype. Clinical Genetics 87(1): 34-41.

Schupbach, D.,M. Comeau-Gauthier,E. Harvey and G. Merle (2020). Wnt modulation in bone healing. Bone 138: 115491.

Simsek Kiper, P.O.,H. Saito,F. Gori,S. Unger,E. Hesse,K. Yamana,R. Kiviranta,N. Solban,J. Liu,R. Brommage,K. Boduroglu,L. Bonafé,B. Campos-Xavier,E. Dikoglu,R. Eastell,F. Gossiel,K. Harshman,G. Nishimura,K.M. Girisha,B.J. Stevenson,H. Takita,C. Rivolta,A. Superti-Furga and R. Baron (2016). Cortical-Bone Fragility — Insights from sFRP4 Deficiency in Pyle's Disease. New England Journal of Medicine 374(26): 2553-2562.

Sinder, B.P.,A.R. Pettit and L.K. McCauley (2015). Macrophages: Their Emerging Roles in Bone. Journal of Bone and Mineral Research 30(12): 2140-2149.
Singh, M. and G. Gonegandla (2019). Bisphosphonate-Induced Osteonecrosis of the Jaws (BIONJ). Journal of Maxillofacial and Oral Surgery 19.

Sugiyama, T. and H. Oda (2017). Osteoporosis Therapy: Bone Modeling during Growth and Aging. Frontiers in Endocrinology 8(46).

Szenker-Ravi, E.,U. Altunoglu,M. Leushacke,C. Bosso-Lefèvre,M. Khatoo,H. Thi Tran,T. Naert,R. Noelanders,A. Hajamohideen,C. Beneteau,S.B. de Sousa,B. Karaman,X. Latypova,S. Başaran,E.B. Yücel,T.T. Tan,L. Vlaminck,S.S. Nayak,A. Shukla,K.M. Girisha,C. Le Caignec,N. Soshnikova,Z.O. Uyguner,K. Vleminckx,N. Barker,H. Kayserili and B. Reversade (2018). RSPO2 inhibition of RNF43 and ZNRF3 governs limb development independently of LGR4/5/6. Nature 557(7706): 564-569.

Tabatabaei-Malazy, O.,P. Salari,P. Khashayar and B. Larijani (2017). New horizons in treatment of osteoporosis. DARU Journal of Pharmaceutical Sciences 25: 2.

Tang, Y.,X. Wu,W. Lei,L. Pang,C. Wan,Z. Shi,L. Zhao,T.R. Nagy,X. Peng,J. $\mathrm{Hu}, \mathrm{X}$. Feng, W. Van Hul,M. Wan and X. Cao (2009). TGF- $\beta 1-$ induced migration of bone mesenchymal stem cells couples bone resorption with formation. Nature Medicine 15: 757.

Tu, K.N.,J.D. Lie,C.K.V. Wan,M. Cameron,A.G. Austel,J.K. Nguyen,K. Van and D. Hyun (2018). Osteoporosis: A Review of Treatment Options. Pharmacy and Therapeutics 43(2): 92-104.

van Lierop, A.H.,N.M. Appelman-Dijkstra and S.E. Papapoulos (2017). Sclerostin deficiency in humans. Bone 96: 5162. 
Van Wesenbeeck, L.,E. Cleiren,J. Gram,R.K. Beals,O. Bénichou,D. Scopelliti,L. Key,T. Renton,C. Bartels,Y. Gong,M.L. Warman,M.C. De Vernejoul,J. Bollerslev and W. Van Hul (2003). Six novel missense mutations in the LDL receptor-related protein 5 (LRP5) gene in different conditions with an increased bone density. American journal of human genetics 72(3): 763-771.

Vestergaard, P.,L. Rejnmark and L. Mosekilde (2005). Reduced relative risk of fractures among users of lithium. Calcif Tissue Int 77(1): 1-8.

Yasuda, H. (2021). Discovery of the RANKL/RANK/OPG system. Journal of Bone and Mineral Metabolism 39(1): 2-11.

Yuan, F.-L.,M.-D. Zhao,L.-B. Jiang,H.-R. Wang,L. Cao,X.-G. Zhou,X.-L. Li and
J. Dong (2014). Molecular actions of ovarian cancer $\mathrm{G}$ protein-coupled receptor 1 caused by extracellular acidification in bone. International journal of molecular sciences 15(12): 22365-22373.

Yuan, Z.,Q. Li,S. Luo,Z. Liu,D. Luo,B. Zhang,D. Zhang,P. Rao and J. Xiao (2016). PPAR $\gamma$ and Wnt Signaling in Adipogenic and Osteogenic Differentiation of Mesenchymal Stem Cells. Curr Stem Cell Res Ther 11(3): 216-225.

Zamani, A.,G.R. Omrani and M.M. Nasab (2009). Lithium's effect on bone mineral density. Bone 44(2): 331-334.

Zohar, R. (2012). Signals Between Cells and Matrix Mediate Bone Regeneration. In).

\section{مسار ونت ودوره كمنظم لعمليتي ثكوين العظم و شفائه}

$$
\text { محمد السويديa، سحر السويفيط، نور هان بركةة، سالي حمادa }
$$

قسم الكيمياء الحيوية ـ كلية الصيدلة ـ جامعة الزقازيقa وجامعة الدلتاb - جمهورية مصر العربية.

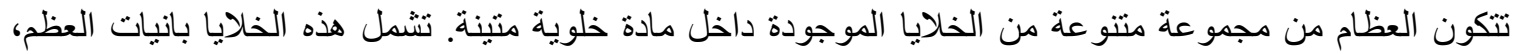

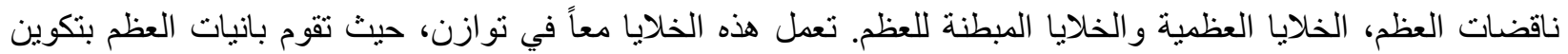

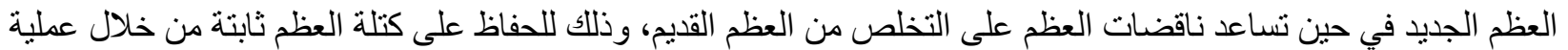

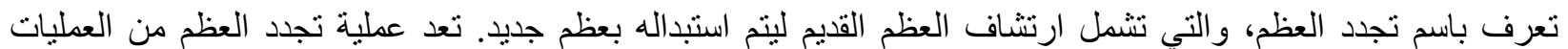

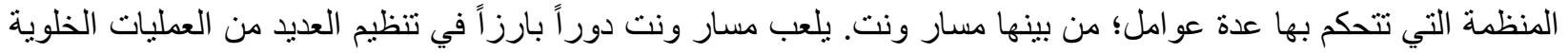

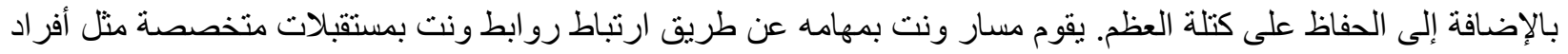

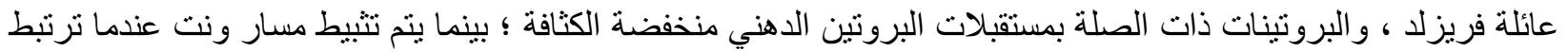

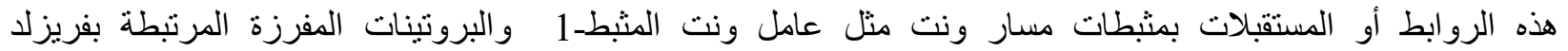

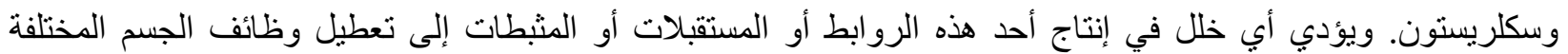

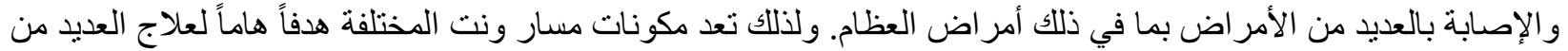
الأمر اضاض. 